\title{
COLO 205
}

National Cancer Institute

\section{Source}

National Cancer Institute. COLO 205. NCI Thesaurus. Code C117159.

An adenocarcinoma cell line established from the ascites fluid of a 70 year old Caucasian

male with colon carcinoma. 